\title{
Financial Development and Economic Growth Relationship: An Analysis with Credit Based Financial Index
}

\section{Yesim Helhel $^{\mathrm{a}}$}

Abstract: Countries are classified under different group names because of their similarity to each other, and they are analyzed in that way by various international organizations. BRICS, MENA, G7 and Fragile Five are well known group names. In this study, the relationship between financial development and economic growth for Fragile five countries (Brazil, India, Indonesia, South Africa and Turkey) through the period of 2002-2016 were examined using annual data. In emerging market economies, businesses prefer to meet their financing needs by asking for credit from the capital market, mostly from banks and non-bank financial institutions. Therefore, it would not be wrong to say that financial system of Fragile Five countries is based on "lending financial institutions". Within the framework of the analysis, financial development index which includes three data related with credit provided by banks and financial institutions, and national income per capita as an economic growth variable were taken into account. Panel co-integration, VECM, DOLS and FMOLS tests have revealed the existence of a unidirectional causality relation from growth towards financial development.
Keywords: Credit Markets, Economic Growth, Fragile Five Countries, VECM, DOLS and FMOLS Tests

JEL: B26, G15, O16

Received : 21 September 2018

Revised : 16 October 2018

Accepted : 24 October 2018

Type : Research

\section{Introduction}

The relationship between the financial system and the real sector has been at the forefront of the issues discussed in the literature for many years. Although there is general consensus that financial development is the determinant of economic growth, there is no consensus on the direction of the relationship between them. Empirical studies on causality analysis are continuing for different groups of countries with new data sets and technical analysis methods developed today. The direction of the causality relationship between finance and growth is a subject of many economics and finance research because it has the potential to make predictions for future and to affect political decisions.

With the globalization that began in the 1980s, the integration of financial markets gained momentum and the need to adopt the financial liberalization policy of emerging economies seeking to be at the forefront of global competition and raising the level of prosperity has emerged. In those years, a number of studies have examined the relationship between the financial system and economic growth in the context of endogenous growth models (Bencivenga \& Smith, 1991; Greenwood \& Jovanovic, 1990; King \& Levine, 1993). Within the framework of the endogenous growth model, an improved financial system stimulates productivity by supporting potential entrepreneurship, and thus innovation-enhancing activities with high likelihood of success bring about economic growth (King \& Levine, 1993). Similarly, Bencivenga and Smith 
(1991) argued that economic growth can be achieved by advanced financial intermediary institutions that offer diversified portfolio services which increase liquidity with minimal risk to households to finance highyield investments. Levine (1997) stated that financial markets, instruments and agreements that reduce the cost of transactions and acquired knowledge for the purpose of accelerating capital accumulation and technological innovation cause economic growth. Note that, in these studies, the hypotheses that financial development determines economic growth is defended. Shumpeter (1911), who advocated this idea on a theoretical basis about a century ago, stated that a financial system with a well-functioning credit system would accelerate economic growth by supporting $R \& D$ and innovation activities. In the following years, some economists have undertaken studies (Gurley \& Shaw, 1955; Goldsmith, 1969; Shaw, 1973; Mckinnon, 1973), which consider that financial development is a necessary condition for high economic growth. In his article, Patrick (1966) wrote and stated this view as "supply-leading hypotheses".

Robinson (1952) argued that financial development is part of economic development and that the demand for financial services in a growing economy has increased and thus financial sector has developed itself due to this inevitable reaction. His argument was the basis of the "demand-following hypotheses". Kuznets (1955), Friedman and Schwartz (1963) are pioneer researchers working on the idea that economic growth supports financial development. Patrick (1966) stated that the main reason for the emergence of modern financial institutions and services is the result of increasing demands of the real sector for these institutions and services. According to Romer (1990) and Stem (1989), the development in the finance sector is facilitated by growth in the real sector.

Some of the studies investigating the relationship between financial development and economic growth have reached the conclusion that both variables affect each other simultaneously. For example, Greenwood and Jovanovic (1990) 's theoretical study speaks of the fact that financial intermediaries support investment and growth by providing a higher rate of return on capital, and that growth also supports the expansion of financial institutions, so causality runs in both directions simultaneously. Similarly, some studies noted that the quality and diversity of services provided by the banking sector increases with economic growth (Ireland, 1994; Demetriades \& Luintel, 1996; Luintel \& Khan, 1999).

There are studies in the literature that cannot determine the relationship between financial development indicators and growth. The most widely known of these is studied by Lucas (1988) named as "On the Mechanics of Economic Development". In the study, the impact of financial development on economic growth was not found, but it was revealed that there was a contribution of human and physical capital to the growth. It is argued that the finance-growth relationship can be negligible in short term, but it can be like a reversed $U$ in long term in some studies. In one of them, the determination of the non-uniformity of the relationship between these two was confirmed by establishing a threshold model and the negative effect of financial development on growth in middle income countries was found (Samargandi et al., 2015). The study of Cecchetti and Kharroubi (2012) indicates that financial sector loans in the private sector have a negative impact on the economic growth when credits provided by banks as percent of GDP exceed $90 \%$. Similarly, Arcand et al (2012), who investigated the relationship between finance and growth by using different country groups and industry data, found the existence of a non-linear relationship in the developed countries when the credits to private sector as percent of GDP exceeded $110 \%$. Deidda and Fattouh (2002) analyzed the data of 119 countries by applying the threshold regression method and concluded that the finance-growth nexus in the developed countries is strong, and it is very weak in the developing and underdeveloped countries. This result is consistent with panel model results analyzed for 74 countries using data from 1961-1995 by Rioja and Valev (2004).

In this study, the relationship between financial development and economic growth for the period 2002-2016 was examined using annual data for (old) Fragile Five countries where Turkey is noted as part of this group. In emerging market economies, businesses prefer to meet their financing needs by asking for credit from the financial markets, mostly from banks and non-bank financial institutions. Therefore, it will not be wrong to say that the financial system of (old) fragile countries (Brazil, Indonesia, South Africa, India and Turkey) is based on "lending financial institutions". Access to the bank and other financial institutions' lending mechanism permits real sector to carry out new investment and projects, which trigger economic 
development. There are many factors in determining loan supply. This mechanism is closely related to the development level of financial system. Advanced and well financial system, including lending institutions, contributes the savings into investment by selecting the most productive ones for these funds and makes sure the use of these funds in high profitable activities. In the lending intermediary process, the funds needed by real sector are supplied and lack of investment resulted from lack of equity is removed. Especially in developing countries, lack of savings is a major problem which brings about many difficulties in financing investments. Moreover, inadequate functioning lending financial system may tend to transfer the limited savings to low-productivity investments. In this situation, achieving economic growth by prompting real sector may be difficult. In this respect, the interaction between loans provided by financial system and economic growth and the direction of this interaction are valuable subjects. This study is mainly shaped within the framework of these questions.

Within the framework of the analysis, credit market based financial development index, which includes three different data related with loans, credits (including state entities) provided by commercial banks, domestic credit provided by banks and domestic credit provided by financial institutions was constructed. Per capita GDP was taken into account as an economic growth variable. The Pedroni cointegration test was applied to determine if there is a long-run equilibrium relationship between variables, the direction of causality was checked as a result of the VECM, and DOLS and FMOLS panel co-integration estimation techniques were used to estimate the long-term coefficients

The novel characteristics of this study from other studies involving financial development and economic growth in the literature can be expressed as follows: Firstly, studies are mostly focused solely on exploring the impact of the commercial banking market on economic growth. The number of studies that analyze the direction of the causality relationship between financial development data on non-bank lenders and growth, especially on developing countries is very limited. Second, a limited number of studies in the literature have examined the relationship between economic growth and financial development index. When those indexes were constructed, the parameters of capital market and its sub-market called stock were included (Cooray, 2010; Samargandi et al., 2015). This study is intended to contribute the literature by examining the relationship between the economic growth and financial development index including parameters belonging only to lender institutions (Pradhan et al., 2014; Seven \& Yetkiner, 2016). Third, there is little to examine the relationship between the financial development parameters and economic growth taking into account Five Fragile countries in question, and to the best our knowledge, similar current studies have different methods, data and periods on Fragile countries (Hayaloglu, 2015; Demetriades et al., 2017).

The remainder of this paper is structures as follows: Section 2 provides a literature review on the connection between economic growth and financial sector development. Section 3 describes variables and model constructed. Section 4 presents analysis method and findings and the last section provides conclusions and comments drawn from the analysis

\section{Theory and Literature}

The literature which is related with financial development and economic growth nexus is mainly composed of studies using cross section, time series and panel data analysis. The parameters used as a measure of financial development can be grouped as banking market, capital market, and other indicators of the financial system. Another grouping can be done by determining the existence of the relationship and determining the direction of the causality. In this section, the studies that examined the relationship based on banking-based data are mentioned.

The most well-known example of these studies is the study by King and Levine (1993), which covers the period of 1960-1989 in 80 countries, supporting the impacts of banking sector on economic growth. Gregorio and Guidotti (1995) considered "the bank loans to private sector as percent of GDP" as the measure of financial development and investigated its impact on economic growth. As a result of the analysis, it has been emphasized that financial development triggers economic growth in general but growth in Latin 
American countries, especially in the term of financial liberalization, has been found to be negatively affected.

On the other hand, studies that examine bidirectional relationship between financial market and economic growth are quite extensive. Demetriades and Hussein (1996), Blackburn and Huang (1998), Luintel and Khan (2001), Calderon and Liu (2002) and Al-Yousif (2002) are bi-directional researchers. Shan and Jianhong (2006) found mutual causality between financial development and growth in the study conducted on China with the VAR and Granger causality test. Yaprakli (2007) revealed that there are mutual causality relationships between growth and financial development, and trade openness for Turkey. Similarly, Altunc (2008) examined the causality nexus between financial development and growth by using the ratio of $M 2$ money supply, domestic credits provided by banking sector, total financial assets and marketable securities to GDP for the period 1970-2006 in Turkey. The findings in the paper indicate bidirectional causality between financial development and growth.

Some studies claimed evidence in favor of "demand-following hypotheses" where the causality runs from economic growth financial sector. Kar and Pentecost (2000), in their study for Turkey by applying VAR and Granger causality test, has concluded that economic growth pioneered to development of the financial sector. Thangavelu and James (2004) found that there is a casual relationship from economic growth to financial intermediaries for Australia in the period of 1960-1999. Hassan vd (2011) demonstrated that there is a casual relationship from economic growth to financial development for the members of Islamic cooperation organization in the period of 1980-2005 by VAR and panel regression analysis.

Particularly in multinational studies, it is impossible to reach a general conclusion, but different results can be obtained for different country groups. Demirgüc-Kunt and Levin (2001) found that both the banking and stock market developments contributed more to growth in countries with high income levels. Rioja and Valev (2004) investigated the impact of financial development on economic growth during the period 1961-1995 by separating 74 countries into three groups. According to the results of analysis; there is no statistically relationship between financial development and growth in underdeveloped countries, while a strong correlation has been found in developed countries due to the contribution of finance to productivity raise. Hassan et al. (2011) analyzed 168 countries by separating several subgroups. They revealed that there is a negative relationship between the domestic credit to private sector and growth in high-income countries, and a positive relationship between them for East Asia, the Pacific, Latin America and the Caribbean. Rachdi and M'barek (2011) conducted a time series and panel data analysis on 6 OECD and 4 MENA countries covering the period 1996-2001. As a result of the analysis, it was determined that there is a bi-directional causality between financial development and economic growth for OECD countries, and unidirectional causality from economic growth to financial development for MENA countries. Barajas et al. (2013) investigated if the effect of financial deepening on economic growth varies among countries using dynamic panel data analysis for 150 countries. It has been stated that this relationship is heterogeneous according to criteria such as region, income level, oil importer or oil exporter, and the level of depth in the banking market is more dominant than capital market on economic growth. Mhadhbi (2014) analyzed 100 developed and developing countries by applying the dynamic panel data method in the period of 1973-2002. According to the findings of the analysis, financial depth has positive impact on economic growth in developed countries, and negative impact in developing countries. Rioja and Valev (2014) concluded that the development of the banking market in low-income countries positively affects growth by increasing capital accumulation, but stock market does not contribute to growth in those countries. They also noted that there is a positive impact of stock market development on growth in high-income countries.

Another research theme is the relationship between financial development, which include both banking and stock market together, and economic growth. Levine and Zervos (1998) found that both markets had a strong impact on economic growth in a cross-sectional analysis of 47 countries during the period 19761993. Arestis et al. (2001) investigated the impact of banking and stock market development on economic growth by using quarterly data of developing countries. The results of time series analysis demonstrate that both the banking and the stock market support growth, but banking is more effective. Beck and Levine (2004) have applied the dynamic panel data method to reveal a positive impact of banking and stock market on 
economic growth. Wu et al. (2010) analyzed the effect of financial institutions on economic growth by using panel data method covering data from 13 European Union countries for the period 1976-2005. One important outcome is the existence of a long-term relationship between the banking sector, the stock market and economic development. Another outcome tells that the financial depth negatively affects the amount of real output in the long-term. Researchers have also emphasized that commercial banks can achieve a steady growth by improving the quality of risk distribution and information service to eliminate negative effect. Sever and Yetkiner (2016) analyzed whether the relationship between banks, stock markets and economic growth varied according to the development level of countries. They took the period of 1991-2011 into account, and applied panel data analysis. Analysis results indicate that banking market development affects growth positively in low- and middle-income countries, and affects growth negatively in high-income countries. While stock markets and banking are in a positive interaction in medium- and high-income countries, an advanced financial system is not always a sufficient factor for growth in developed countries, unlike developing countries. Puryan (2017) examined the relationship between growth and banking and stock market in MENA countries for the period of 1988-2012. He used four different indexes to measure development of banking and stock market sectors. As a result of the analysis using Granger causality and vector error correction model (VECM), there is a bi-directional causality between stock market development and economic growth. At the same time, there is one way causality from banking development toward stock market development, and the stock market has a positive effect on growth in the long term. Murari (2017) used a data set in the period of 1980-2003 for South Asian countries, and made his conclusions by means of panel data analysis. As an outcome, he found that the domestic financial sector loans to the private sector and domestic credit provided by banking did not adequately support growth due to weak financial system, lack of audit and frequent problems in credit allocation. In turn, the stock market capitalization rate and liquidity support economic growth.

\section{Data and Model}

This analysis utilizes annual time series data over the 2002-2016 for Fragile Five which includes Brazil, Indonesia, Republic of South Africa, India and Turkey. The data for each country are obtained from the World Bank Global Financial Development Database and the World Development Indicators Database published by the World Bank. Since Eviews-9 statistical software package allows users to develop statistical relations among series and manipulate the results and output, it is preferred to use in analysis.

The first variable used in the study is financial development index, which is formed of three creditbased market indicators, and the second one is per capita economic growth in logarithmic form. Table 1 lists the definitions of variables used in the forming of credit based financial development index.

Table 1. Definitions of Variables Used in Credit-based Market

\begin{tabular}{|l|l|}
\hline Variable & Definition \\
\hline CFI & Composite index of credit based market development \\
\hline BCR & Credits provided by commercial banks as percent of GDP (It includes credit to public enterprises) \\
\hline DCR & Domestic credit provided by banks as percent of GDP \\
\hline FCR & Domestic credit provided by financial sector as percent of GDP \\
\hline
\end{tabular}

Note 1: CFI is computed by researcher.

Note 2: All variables above are published yearly by the World Bank.

The general form of the causality relationship between economic growth and the credit-based financial variable in the study was tested by establishing two models as described in Eq(1), where $\ln P C_{i t}$ is the real GDP per capita in logarithmic form, and $C F I_{i t}$ is financial development index of the country $i$ for year $t$, $\epsilon_{i t}$ is the error term, $\alpha$ is unknown group effects; $B_{1 i}$ is the co-integration coefficient. 


$$
\ln P C_{i t}=\alpha_{i}+\beta_{1 i} C F I_{i t}+\varepsilon_{i t} \quad \mathrm{i}=1,2, \ldots \ldots, \mathrm{N} ; \mathrm{t}=1,2 \ldots \ldots \ldots . . \mathrm{t}
$$

We also evaluate reverse effect, that is, "economic growth causes financial development" and feedback effect, that is, mutual causality occurs between financial development and economic growth," therefore the equation can be written as in Eq (2).

$$
C F I_{i t}=\alpha_{i}+\beta_{1 i} \ln P C_{i t}+\mu_{i t}
$$

In the study, firstly the stationary of the panel time series are tested. When panel data is used, it is necessary to test cross sectional dependence for the unit root test. If cross sectional dependence is rejected, the first generation unit root tests can be used. Otherwise, the use of second-generation unit root tests allows more consistent results. $C D_{L M 1}$ and $C D_{L M 2}$ tests are used in the case of $\mathrm{T}>\mathrm{N}$ to measure the cross sectional dependency. Since the study has 5 countries (N) and 15 years (T) covering the period of 2002-2016, $C D_{L M 1}$ and $C D_{L M 2}$ tests are used. The null hypothesis is accepted statistically as the results obtained, and it is found that there is no cross sectional dependency in the panel data set. For this reason, Levin-Lin-Chu (LLC) and ImPeseran-Shin (IPS) tests are applied as intercept, intercept and trend.

\section{Method \& Findings}

In Table 2, the results of the LLC and IPS tests are reported as intercept, intercept \& trend in level and first-differenced forms. The results reveal that both series are non-stationary in the presence of intercept, intercept and trend at level, but found to be stationary at first difference.

\begin{tabular}{|c|c|c|c|c|}
\hline \multirow[t]{2}{*}{ Variable } & \multicolumn{2}{|r|}{ CFI } & \multicolumn{2}{|r|}{$\ln P C$} \\
\hline & Intercept & Intercept \& Trend & Intercept & Intercept \& Trend \\
\hline \multicolumn{5}{|l|}{ Level } \\
\hline LLC & $0.135(0.553)$ & $1.619(0.947)$ & $-4.543 *(0.000)$ & $-0.523(0.300)$ \\
\hline IPS & $-0.623(0.266)$ & $1.230(0.890)$ & $-2.345 *(0.009)$ & $2.368(0.991)$ \\
\hline \multicolumn{5}{|c|}{ 1st Difference } \\
\hline LLC & $-3.441 *(0.000)$ & $-2.275 *(0.000)$ & $-4.392 *(0.000)$ & $-6.027 *(0.000)$ \\
\hline IPS & $-4.940 *(0.000)$ & $-1.973 * *(0.030)$ & $-2.266^{* *}(0.011)$ & $-3.254 *(0.000)$ \\
\hline
\end{tabular}

Table 2. Results from Panel Unit Root Test

Note $1{ }^{*}$ and ${ }^{* *}$ denote significance at $1 \%$ and $5 \%$, respectively.

Note 2: Numbers in parenthesis denote $p$-values.

Note 3: Schwarz Info Criterion is taken into consideration determining optimal lag length.

Note 4: Barlett and Newey-West bandwith are used as parameters.

In the second step, Pedroni panel co-integration test is used to determine if there is long-run equilibrium (co-integration) between financial development index and economic growth. The null hypothesis of no integration is evaluated, based on seven test statistics. The seven statistics in the Pedroni are classified into with-in dimension which includes four panel statistics and between-dimension which includes three panel statistics. It can be told that if the majority of seven test statistics are found as significant at 1-5\% levels, the null hypothesis of no co-integration is rejected, and the availability of co-integration (long-run equilibrium) is accepted.

As can be seen in Table 3, the majority of the seven statistics with trend and without trend are statistically significant, indicating the existence of a long-run equilibrium relationship between financial development index and economic growth. 
Table 3. Results of Pedroni Panel Co-integration Test

\begin{tabular}{|l|r|r|}
\hline Pedroni Co-integration & \multicolumn{2}{|c|}{$\Delta$ CFI $-\Delta$ InPC } \\
\hline Test & No intercept or trend & \multicolumn{1}{c|}{ Individual intercept } \\
\hline Panelv & $5.262^{*}(0.000)$ & $-3.101^{*}(0.001)$ \\
\hline Panelrho & $-2.582^{*}(0.004)$ & $-2.034^{* *}(0.021)$ \\
\hline PanelPP & $-1.717^{* *}(0.042)$ & $-1.774^{* *}(0.038)$ \\
\hline PanelADF & $-2.213^{* *}(0.013)$ & $-2.410^{*}(0.008)$ \\
\hline Grouprho & $-0.379(0.352)$ & $-0.539(0.294)$ \\
\hline GroupPP & $-1.834^{* *}(0.033)$ & $-2.737^{*}(0.003)$ \\
\hline GroupADF & $-2.081^{* *}(0.018)$ & $-2.899 *(0.001)$ \\
\hline
\end{tabular}

Note 1: $\Delta$ denotes $1^{\text {st }}$ differenced of variable.

Note 2: ${ }^{*}$ and ${ }^{* *}$ denote significance at $1 \%$ and $5 \%$, respectively.

Note3: Null hypothesis is that variables are not co-integrated.

According to Granger (1988), if there is a co-integrated vector between the variables, it is necessary to have at least one-way causality between the variables. If the variables are integrated of order one I( 1 and cointegrated, it is recommended to use the VECM (vector error correction method) model instead of the panel VAR method, because VAR does not take the term of error correction that rectifies short run non-equilibrium into account (Anwar \& Nguyen, 2009). Since this method allows distinguishing the direction of causality in the short and long-run, it has an advantageous position. If the coefficient on the ECT is significantly negative, the long run relationship among time series occurs. As can be seen in Table 4, the coefficient of estimate on the ECT is negatively significant and lies from InPC to CFI. The results of the analysis demonstrated the validity of a "demand-following" view, where causality runs from economic growth to credit-based financial development index. This result is consistent with the findings of Peia and Roszbach (2015) who examined for 22 developed countries and Helhel (2017a, 2017b) who analyzed for E7 countries. Peia and Roszbach (2015) post that financial development in the countries where financial markets are capital-based, is the reason of economic growth, whereas economic growth is the reason of financial development for countries with banking-based financial markets. Rana and Barua (2015) concluded through panel regression analysis that the total credit volume and M3 money supply do not contribute to the growth of the South East Asian countries. In the study of OECD countries conducted by Aydın and Malcioglu (2016), the contribution of the credit provided by financial sector to the economic growth is searched and a one-way causality relationship is found from financial development to economic growth. Our result is also inconsistent with findings of Pradhan et al. (2014) that support supply-leading hypothesis, banking sector development causes economic growth. Menyah et al. (2014) who formed financial development index based on four different financial development indicators for 21 African countries found limited support for the finance-led growth. Mukhopadhyay et al. (2011) suggested mixed evidence on the finance-growth relationship in the context of the Asian countries employing the ratio of total credit to the private sector to nominal GDP and deposit liabilities of the banking sector to nominal GDP as financial development indicators.

Table 4. Causality Based on Panel VECM Estimations

\begin{tabular}{|lccc|}
\hline Variables & Direction of Causality & p-value & $\mathrm{ECT}_{t-1}$ \\
\hline$\Delta \mathrm{CFI}-\Delta \mathrm{lnPC}$ & - & 0.068 & -0.337 \\
$\Delta \mathrm{InPC}-\Delta \mathrm{CFI}$ & $\rightarrow$ & $0.001^{*}$ & -0.117 \\
\hline
\end{tabular}

Note 1: $\mathrm{ECT}_{\mathrm{t}-1}$ is the lagged error-correction term.

Note 2: ${ }^{*}$ denotes significance at $1 \%$. 
DOLS (dynamic least squares method) and FMOLS (fully corrected least squares method) are used to estimate the long term coefficients of time series in the continuation of study. In both models, the effect of economic growth on the credit-based financial index is assessed, taking into account the results of the VECM causality test. As displayed in Table 5, the results of both tests are parallel to each other and confirm the results of VECM causality test. When the economic size (per capita income) increases by $1 \%$, the credit-based financial development index is positively and statistically affected by $0,252 \%$ in the evaluation of estimated coefficient values according to the DOLS results. Similarly, a $1 \%$ increase in economic growth has a positive and statistically significant effect on the financial development index of $0,238 \%$ according to FMOLS estimator results. Law et al $(2014,2015)$ found that there is no statistically significant effect of per capita income on market capitalization rate and private sector loans in two separate studies by applying the DOLS and FMOLS tests. Nasreen et al. (2015) conducted FMOLS test and found that banking sector loans, private sector loans provided by financial institutions and other financial indicators which are defined as financial development have positive effect on growth.

Table 5. Results from DOLS \& FMOLS Estimation

\begin{tabular}{|c|c|c|c|}
\hline \multirow{4}{*}{ Dependent Variable ( $\Delta$ CFI) } & \multicolumn{3}{|c|}{ Independent Variable $(\Delta \operatorname{lnPC})$} \\
\cline { 2 - 4 } & \multicolumn{3}{|c|}{ DOLS } \\
\cline { 2 - 4 } & Coefficient & t-statistics & Probability \\
\cline { 2 - 4 } & 0.252 & $0.097^{* *}$ & 0.013 \\
\cline { 2 - 4 } & \multicolumn{3}{|c|}{ FMOLS } \\
\cline { 2 - 4 } & Coefficient & t-statistics & Probability \\
\cline { 2 - 4 } & 0.238 & $0.068^{*}$ & 0.000 \\
\hline
\end{tabular}

Note: ${ }^{*}$ and ${ }^{* *}$ denote significance at $1 \%$ and $5 \%$, respectively.

\section{Conclusion}

While the concept of economic growth and development has already been an important target of developed countries, it has also become the most important target for the emerging countries due to the increase of commercial and financial relations among countries with the role of globalization. Although the economic growth concept represents a quantitative increase in income, the per capita is an indicator of wealth. For this reason, there should be sustainable economic growth within the primary politics of the governments. Policies applied to economic growth targets have a very complex and detailed content both on theoretical and empirical scale. This study is limited only focusing on the relationship between growth and financial market, including lending financial institutions. The variables used in the study are per capita economic growth, and financial development index, which is composed of three credit-based market indicators. Panel data test results in the period of 2002-2016 using annual data show a long-run relationship between growth and credit-based financial index, for emerging market economies called the Five Fragile. The VECM causality test indicates the causal relationship between financial development and economic growth so that the direction of relationship is from economic growth to financial development. In other words, the results support the "demand-following" hypotheses.

DOLS and FMOLS methods are used to estimate the final unbiased coefficients of the independent variables. The results obtained in DOLS and FMOLS demonstrated that the effect of economic growth on financial development index is found to be positive and significant at $5 \%$ and $1 \%$, respectively. Findings seem to be consistent with the economic and financial development processes of developing countries. In general, considerable improvement has been realized as a result of the reforms to promote financial markets especially in the last 20 years in these countries. Nevertheless, as expected in the theoretical framework, the expansion of the credit pool to finance investments has not supported economic growth. In spite of the financial reforms implemented, it may be the two main reasons of failed intermediation function of the 
banking system that channels savings into investment. The first of these is the purchase of treasury debt securities issued for public finance by banks. Banks prefer to finance the public sector by purchasing mostly zero-risk treasury debt instruments in the hope of removing/reducing distortions in fiscal balance that are more common in emerging markets rather than financing the productive investment of real sector with the majority of the funds they obtain from the country and abroad. Second is the inadequate and unsuccessful policy on savings in financial system to transfer to productive investments and priority sectors to accelerate growth.

\section{References}

Ak, M. Z., Altıntaş, N., \& Şimşek, A. S. (2016). Türkiye'de finansal gelişme ve ekonomik büyüme ilişkisinin nedensellik analizi. Doğuş Üniversitesi Dergisi, 17(2), 151-160.

Altunç, Ö. F. (2008). Türkiye'de finansal gelişme ve iktisadi büyüme arasındaki nedenselliğin ampirik bir analizi. Eskişehir Osmangazi Üniversitesi iiBF Dergisi, 3(2), 113-127

Al-Yousif, Y. K. (2002). Financial development and economic growth: Another look at the evidence from developing countries. Review of Financial Economics, 1431(1), 179-198.

Anwar, S., \& Nguyen, L. P. (2009). Financial development and economic growth: Evidence from South Asia. Economic Modelling, 29, 974-981

Arcand, J., Berkes, E., \& Panizza, U. (2012). Too much finance? International Monetary Fund (IMF), Research Department.

Arestis, P., Demetriades, P., \& Luintel, K. B. (2001). Financial development and growth: The role of stock markets. Journal of Money Credit Banking, 33, 16-41.

Aydın, M., \& Malcıoğlu, G. (2016). Financial development and economic growth relationship: The case of OECD countries. The Journal of Applied Research in Finance and Economics, 2(1), 1-8.

Barajas, A., Chami, R., \& Yousefi, S. R. (2013). The finance and growth nexus re-examined: Do all countries benefit equally? IMF Working Paper, WP/13/130.

Beck, T., \& Levine, R. (2004). Stock markets, banks and growth: Panel evidence. Journal of Banking Finance, 28(3), 423442.

Bencivenga, V. R., \& Smith, B. D. (1991). Financial intermediation and endogenous growth. The Review of Economic Studies, 58(2), 195-209.

Blackburn, K., \& Huang, V. (1998). A theory of growth, financial development and trade. Economica, 65(257), 107-124.

Calderon, C., \& Liu, L. (2003). The direction of causality between financial development and economic growth. Journal of Development Economics, 72, 321-334.

Cecchetti, G., \& Kharroubi, E. (2012). Reassessing the impact of finance on growth. BIS Working Paper, 381, Bank for International Settlements.

Cooray, A. (2010). Do stock markets lead to economic growth? Journal of Policy Modeling, 32, 448-460.

Deidda, L., \& Fattough, B. (2002). Non-linearity between finance and growth. Economic Letters, 74(3), 339-345.

Demetriades, P. O., \& Luintel, K. B. (1996). Financial development, economic growth and banking sector controls: Evidence from India. The Economic Journal, 106(435), 359-374.

Demetriades, P. O., \& Hussein K. A. (1996). Does financial development cause economic growth? Time series evidence from 16 countries. Journal of Development Economics, 51, 387-411.

Demetriades, P. O., Rousseau, P. L., \& Aewilak, J. (2017). Finance, growth and fragility. University of Leicester Working Paper, No:17/13.

Demirgüc-Kunt, A., \& Levine, R. (2001). Financial structure and economic growth: A cross-country comparison of banks, markets and development. MIT Press, Cambridge, MA.

Friedman, M., \& Schwartz, A. J. (1963). A Monetary History of the United States, 1867-1960. Princeton: Princeton University Press.

Goldsmith, R. W. (1969). Financial Structure and Development. New Haven: Yale University Press.

Greenwood, B., \& Jovanovic, B. (1990). Financial development, growth and the distribution of income. Journal of Political Economy, 98(5), 1076-1107. 
Gregorio, J. D., \& Guidotti, P. E. (1995). Financial development and economic growth. World Development, 23(3), 433448.

Gurley, J., \& Shaw, E. (1995). Financial aspects of economic growth. American Economic Review, 45, 515-537.

Hasan, R., \& Barua, S. (2015). Financial development and economic growth: Evidence from a panel study on South Asian countries. Asian Economic and Financial Review, 5(10), 1159-1173.

Hassan, K., Sanchez, B., \& Yu, J.S. (2011). Financial development and economic growth in the organisation of Islamic conference countries. Islamic Econ, 24(1), 145-172.

Hayaloğlu, P. (2015). Kırılgan beşli ülkelerinde finansal gelişme ve ekonomik büyüme ilişkisi: Dinamik panel veri analizi. Ekonomik ve Sosyal Araştırmalar Dergisi, 11(1), 131-144.

Helhel, Y. (2017a). E7 ülkelerinde finansal gelişme ve ekonomik büyüme arasında nedensellik analizi. Finans Politik \&Ekonomik Yorumlar, 54, 9-18.

Helhel, Y. (2017b). (Eski) kırılgan beşli ülkelerde finansal gelişme ve büyüme ilişkisi. Birsen Yayınevi, Istanbul, ISBN: $978-$ 975-511-668-6.

Ireland, P. N. (1994). Money and growth: An alternative approach. American Economic Review, 84(1), 47-65.

Kar, M., \& Pentecost, E. (2000). The direction of causality between financial development and economic growth in Turkey: Further evidence. Loughborough University, Department of Economics, Economic Research Paper, No:00/27, Dec.

King, R. G., \& Levine, R. (1993). Finance, entrepreneurship and growth: Theory and evidence. Journal of Monetary Economics, 32(3), 513-542.

Kuznets, S. (1955). Economic growth and income inequality. The American Economic Review, 45(1), 1-28.

Law, S. H., Azman-Saini, W. N. W., \& Tan, H. B. (2014). Economic globalization and financial development in East Asia: A panel cointegration and causality analysis. Emerging Markets Finance and Trade, 50(1), 210-225.

Law, S. H., Tan, H. B., \& Azman-Saini, W. N. W. (2015). Globalization, institutional reforms and financial development in East Asian Economies. The World Economy, doi: 10.1111/twec.12168.

Levine, R., \& Zervos, S. (1998). Stock markets, banks and economic growth. American Economic Review, 88(3), 537-558.

Lucas, R. E. (1988). On the mechanics of economic development. Journal of Monetary Economics, 22(1), 3-42.

Luintel, K., \& Khan, M. (1999). A quantitative reassessment of the finance-growth nexus: Evidence from a multivariate VAR. Journal of Development Economics, 60(2), 381-405.

McKinnon, R. I. (1973). Money and Capital in Economic Development. Washington DC: The Brooking Institution.

Menyah, K., Nazlioglu, S. \& Wolde-Rufael, Y. (2014). Financial development, trade openness and economic growth in African countries: New insights from a panel causality approach. Economic Modelling, 37(2), 386-394.

Mhadhbi, K. (2014). Financial development and economic growth: A dynamic panel data analysis. International Journal of Econometrics and Financial Management, 2(2), 48-58.

Mukhopadhyay, B., Pradhan, R. P., \& Feridun, M. (2011). Finance-growth nexus revisited for some Asian countries. Applied Economics Letters, 18(16), 1527-1530

Murari, K. (2017). Financial development-economic growth nexus: Evidence from South Asian Middle-income countries. Global Business Review, 18(4), 924-935.

Nasreen, S., Mahalik, M. K., Abbas, Q., \& Shahbaz, M. (2015). The interaction between financial development, globalization, institutions and growth: The statistical experience from 23 European countries. COMSATS, Department of Management Sciences, Working Paper, 2015-011.

Patrick, H. T. (1966). Financial development and economic growth in underdeveloped countries. Economic Development and Cultural Change, 14,174-189.

Peia, O., \& Roszbach, K. (2015). Finance and growth: Time series evidence on causality. Journal of Financial Stability, 19, 105-118

Pradhan, R. P., Arvin, M. B., Hall, J. H., \& Bahmani, S. (2014). Causal nexus between economic growth, banking sector development, stock market development, and other macroeconomic variables: The case of Aesean countries. Review of Financial Economics, 23, 155-173.

Puryan, V. (2017). The causal relationship between economic growth, banking sector development and stock market development in selected Middle-East and North African countries. International Journal of Economics and Financial Issues, 7(3), 575-580. 
Rachdi, H., \& M'barek, H. B. (2011). The causality between financial development and economic growth: Panel data cointegration and GMM system approaches. International Journal of Economics and Finance, 3(1), 143-151.

Rioja, F., \& Valev, N. (2004). Finance and the sources of growth at various stages of economic development. Economic Inquiry, 42, 127-140.

Rioja, F., \& Valev, N. (2011). Stock markets, banks and sources of economic growth in low and high income countries. J. Econ. Finance, 38(2), 302-330.

Robinson, J. (1952). The Generalization of the General Theory. London: Macmillan.

Romer, P. M. (1990). Endogenous technological change. Journal of Political Economy, 98(5), S71-S102.

Samargandi, N., Fidrmuc, J., \& Ghosh, S. (2015). Is the relationship between financial development and economic growth monotonic? Evidence from a sample of middle-income countries. World Development, 68, 66-81.

Seven, U., \& Yetkiner, H. (2016). Financial intermediation and economic growth: Does income matter? Economic Systems, 40, 39-58.

Shan, J., \& Jianhong, Q. (2006). Does financial development 'lead' economic growth? The case of China. Annals of Economics and Finance, 1, 231-250

Shaw, E. S. (1973). Financial deepening in economic growth. Newyork: Oxford University Press.

Stem, N. (1989). The economics of development: A survey. The Economic Journal, 100, 597-685.

Thangavelu, S., \& James, A. B. J. (2004). Financial development and economic growth in Australia: An empirical analysis. Empirical Economics, 29(2), 247-260

Wu, J., Hou, H., \& Cheng, S. (2010). The dynamic impacts of financial institutions on economic growth: Evidence from the European Union. Journal of Macroeconomics, 32, 879-891.

Yapraklı, S. (2007). Ticari ve finansal dışa açıklık ile ekonomik büyüme arasındaki ilişki: Türkiye üzerine bir uygulama. Ekonometri ve İstatistik, 5, 1-19 
This Page Intentionally Left Blank 